\title{
Heterogeneous Strategies For Selective Conversion of Lignocellulosic Polysaccharides
}

\section{Zhengqiu Yuan ( $\nabla$ yuanzq@pku.edu.cn )}

Hunan University of Science and Technology

Wei Dai

Hunan University of Science and Technology

Shenghong Zhang

Beijing Institute of Petrochemical Technology

Fengxin Wang

CNPC: China National Petroleum Corp

Jian Jian

Hunan University of Science and Technology

Jianxian Zeng

Hunan University of Science and Technology

Hu Zhou

Hunan University of Science and Technology

\section{Research Article}

Keywords: Lignocellulose, Cellulose, Hemicellulose, Heterogeneous catalysis, Solid catalyst, Chemicals

Posted Date: September 20th, 2021

DOI: https://doi.org/10.21203/rs.3.rs-881938/v1

License: (c) (i) This work is licensed under a Creative Commons Attribution 4.0 International License.

Read Full License

Version of Record: A version of this preprint was published at Cellulose on February 28th, 2022. See the published version at https://doi.org/10.1007/s10570-022-04434-8. 


\section{Heterogeneous strategies for selective conversion of}

\section{lignocellulosic polysaccharides}

Zhengqiu Yuan ${ }^{a *}$, Wei Dai ${ }^{\mathrm{a}}$, Shenghong Zhang ${ }^{\mathrm{b}}$, Fengxin Wang ${ }^{\mathrm{c}}$, Jian Jian, Jianxian Zeng ${ }^{\text {a }}$, Hu Zhou ${ }^{\text {a* }}$

a School of Chemistry and Chemical Engineering, Hunan University of Science and Technology, Xiangtan, 411201, P. R. China;

b Beijing Key Laboratory of Enze Biomass Fine Chemicals, Beijing Institute of Petrochemical Technology, Beijing 102617, P. R. China;

${ }^{\mathrm{c}}$ China National Petroleum Corporation (CNPC) Advisory Center, Beijing 100724, P. R. China.

\section{Corresponding author:}

*E-mail: yuanzhengqiu@126.com (Z. Yuan), hnustchem@163.com (H. Zhou)

\section{Abstract}

Lignocellulosic biomass is the most abundant renewable carbon resource on earth, for which many efforts have been made to convert it using various chemocatalytic processes. Heterogeneously chemocatalytic conversion conducted based on reusable solid catalysts is the process with the greatest potential studied presently. This review provides insights into the representative achievements in the research area of heterogeneous chemical catalysis technologies for the production of value-added chemicals from lignocellulosic polysaccharides (cellulose and hemicellulose). Popular approaches for the conversion of lignocellulosic polysaccharides into chemicals, including hydrolyzation (glucose, xylose 
and arabinose), dehydration (5-hydroxymethylfurfuran, furfural and levulinic acid), hydrogenation/hydrogenolysis (sorbitol, mannitol, xylitol, 1,2-propylene glycol, ethlyene glycol and ethanol), selective oxidation (gluconic acid and lactic acid), have been comprehensively reviewed. However, technological barriers still exist, which have to be overcome to further integrate hydrolysis with the refinery processes based on multifunctional solid catalysts, and convert ligncellulosic polysaccharides into value-added fine chemicals. In general, the approaches and technologies are discussed and critically evaluated in terms of the possibilities and potential for further industrial implementation.

Keywords: Lignocellulose; Cellulose; Hemicellulose; Heterogeneous catalysis; Solid catalyst; Chemicals

\section{Introduction}

The depletion of fossil resources and growing concern about environmental issues have accelerated the development of a series of novel chemical processes based on no-fossil sustainable resources, in particular, the biomass and biomass-derived chemicals (Alonso et al. 2017; Mika et al. 2018; Sun et al. 2018b). Lignocellulosic biomass originated from biological photosynthesis is a renewable and green feedstock in abundance with easy availability for the production of fine chemicals and fuels without extra carbon emission. In addition, the production of chemicals and fuels derived from lignocellulose has great 
potential to reduce our dependence on fossil fuel resources, promote national economic growth, and combat global climate change (Alper et al. 2020; Robertson et al. 2017; Staples et al. 2017; Wittwer et al. 2021; Woolf et al. 2016). Over the past decades, the research on the lignocellulose conversion has attracted significant attention from the industry and academia (Ma et al. 2012; Serrano-Ruiz \& Dumesic, 2011; Wang et al. 2020b).

Biochemically, lignocellulosic biomass is a series of material which is rich in cellulose (35-50\%), hemicellulose (15-30\%), and lignin (15-30\%) (Questell-Santiago et al. 2020; Ragauskas et al. 2006). For example, various species, such as grass (e.g. corn stalk and wheat straw), softwood (white pine and larch) and hardwood (Camphor and Birch) are typical sources of lignocellulosic biomass (Liu et al. 2015; Xia et al. 2016). Each of the main components in lignocellulose can be converted into value-added chemicals and platform molecules (Han et al. 2019; Zhang et al. 2017). Therefore, in terms of the availability from renewable bioresources and the security of food supply, lignocellulosic biomass is more practicable and sustainable, which can be utilized as the ideal feedstocks for the production of valuable platform chemicals and biofuels (Alonso et al. 2010; Wang et al. 2020a). 


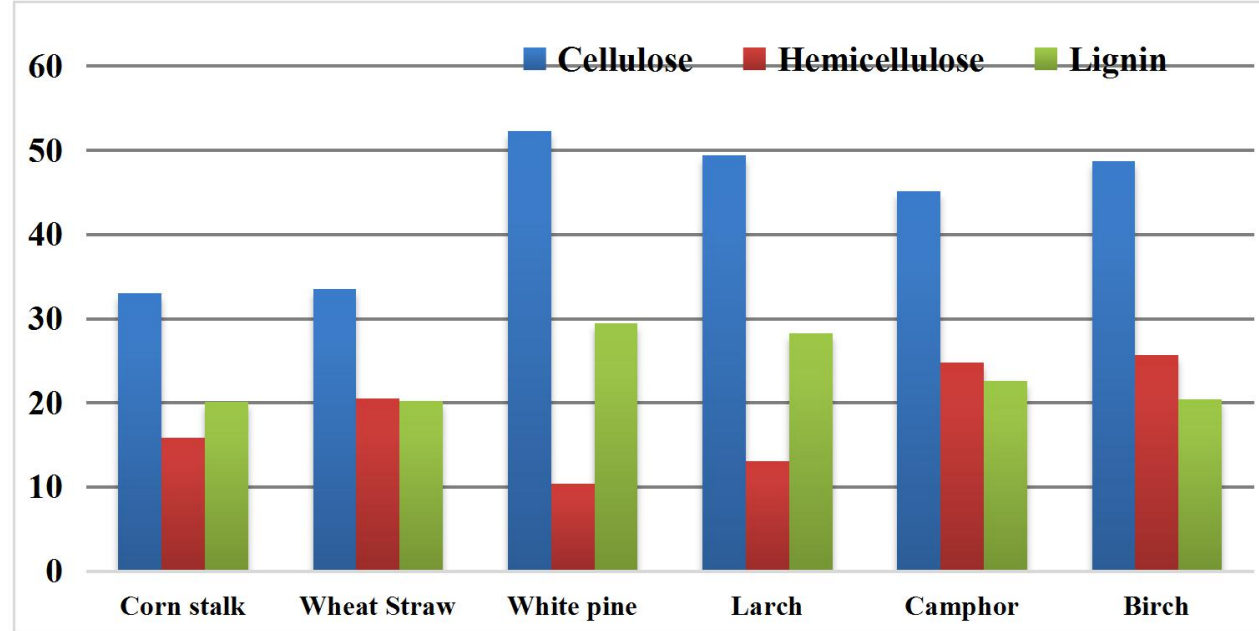

Fig. 1. The weight percentage of cellulose, hemicellulose and lignin in some typical biological sources such as grass (Corn stalk and Wheat straw), softwood (White pine and Larch) and hardwood (Camphor and Birch) (Liu et al. 2015; Xia et al. 2016)

At present, the development of the processes for one-step conversion of lignocellulose into value-added chemicals remains a huge challenge (Gallezot, 2008). In particular, the complex structural constituent of lignocellulose makes it difficult to obtain target chemicals with high yield and quality. As the major component of lignocellulose, cellulose is constructed by repeating anhydrous glucose units, which is covalently linked by $\beta-1,4$-glycosidic bonds with a generic chemical formula $\left(\mathrm{C}_{6} \mathrm{H}_{10} \mathrm{O}_{5}\right)_{\mathrm{n}}$. The linear-chain structure is further tightly confined by the extensive intramolecular and intermolecular bonding networks. Consequently, cellulose has the most ordered and imparted rigid crystallinity. In contrast, as a kind of branched-chain polymer, hemicellulose consists of many different sugar monomers arranged in a random and amorphous structure. Lignin is a three-dimensional amorphous biopolymer composed of phenylpropanoid units which are 
connected by carbon-carbon and ether bonds, showing relative hydrophobic and aromatic properties (Foston \& Ragauskas, 2012; Himmel et al. 2007). Those differences in terms of chemical composition and structure of cellulose, hemicellulose and lignin lead to apparent disparities in their reactivity. Therefore, the efficient chemical conversion of lignocellulose into platform chemicals requires a pretreatment process. Therefore, to obtain high yield monomers or platform chemicals, the corresponding components of lignocellulose have to be released by using a feasible pretreatment (Liheng et al. 2017; Ling et al. 2019; Vanneste et al. 2017).

Over past few decades, many researchers have endeavored to explore the efficient production of value-added chemicals and fuels by means of catalytic conversion of lignocellulose through homogeneous and heterogeneous processes (Jing et al. 2019; Zhang et al. 2019). Among them, heterogeneous catalytic process has received considerable attentions due to the advantages of easy recovery and reusability of solid catalysts (Scarsella et al. 2020; Sudarsanam et al. 2018). In recent years, researchers have made increasing efforts to design multifunctional catalysts to consolidate the two- or multi-step batch processes into a one-step cascade catalytic reaction system. In this manner, lignocellulosic biomass can be directly converted into various essential chemicals in an efficient and environmentally friendly way. As shown in Table 1, some 
109 fractions by using different chemical processes (Chatterjee et al. 2015;

110 Zhang et al. 2016). It is worth nothing that the strategy of "platform

111 chemicals" firstly considers the selective conversion of three components

112 in lignocellulosic biomass (cellulose, hemicellulose and lignin) to

113 platform chemicals via hydrolysis, dehydration,

114 hydrogenation/hydrogenolysis and selective oxidation processes;

115 secondly, the products can be further upgraded from the above platform

116 chemicals (Delidovich et al. 2016; Gérardy et al. 2020; Sun et al. 2018c).

117 Clearly in table 1, a wide range of chemicals, such as monosaccharides,

118 lignin monomers, alcohols, bioorganic acids, furfurals etc. can be

119 obtained through catalytic transformations of lignocellulosic biomass.

120 Table 1 A summary of platform chemicals produced by chemical conversion of 121 lignocellulosic biomass.

\begin{tabular}{|c|c|c|c|}
\hline Fractions & Platform chemicals & Secondary chemicals & End use products \\
\hline \multirow{4}{*}{$\begin{array}{l}\text { Polysaccharides } \\
\text { (Cellulose and } \\
\text { hemicellulose) }\end{array}$} & $\begin{array}{l}\mathrm{C}_{6}, \mathrm{C}_{5} \text { Sugar alcohols } \\
\text { (xylitol, } \\
\text { sorbitol, etc) }\end{array}$ & $\begin{array}{l}\text { Ethylene glycol, propylene } \\
\text { glycol, hydroxyfuran, Sugar } \\
\text { acids }\end{array}$ & $\begin{array}{l}\text { Green solvent, plastic, cosmetics, detergent, } \\
\text { pharmaceuticals }\end{array}$ \\
\hline & $\begin{array}{l}\mathrm{C}_{3} \text { Acids (propionic, } \\
\text { malonic) }\end{array}$ & $\begin{array}{l}\text { Propionyl acrylate, } \\
\text { pharmaceutical intermediates } \\
\text { and reagents }\end{array}$ & $\begin{array}{l}\text { Water purification, dust control, gas } \\
\text { purification, cleaners and detergents, coating, } \\
\text { insulation, preservatives, fertilizers, } \\
\text { pesticides }\end{array}$ \\
\hline & $\begin{array}{l}\text { 3-Hydroxy } \\
\text { propionate }\end{array}$ & Acrylates, acryl amides & $\begin{array}{l}\text { Specialty lubricants, flocculants, chelators, } \\
\text { paint, vamish and coating materials, } \\
\text { insulation, packaging }\end{array}$ \\
\hline & Levulinic acid & $\begin{array}{l}\text { 3-amino levulinate, } \\
\text { succinates } \\
\text { 2-methyltetrahydrofuran, } \\
\text { 1,4-diols, } \gamma \text {-valerolactone }\end{array}$ & $\begin{array}{l}\text { Molded plastics, packaging, fuels, } \\
\text { oxygenates, resin, adhesive, insulator agents, } \\
\text { coatings }\end{array}$ \\
\hline
\end{tabular}




\begin{tabular}{|c|c|l|l|}
\hline & \multicolumn{1}{|c|}{ Furfural } & \multicolumn{1}{|c|}{ Furan derivatives } & $\begin{array}{l}\text { Fuels, oxygenates, textiles, resin, adhesive, } \\
\text { insulator agents, coatings }\end{array}$ \\
\cline { 2 - 4 } & Gluconic acid & Gluconolactones, esters & Cosmetics, pharmaceuticals \\
\hline Lignin & Lignin monomers & $\begin{array}{l}\text { Benzene, toluene, xylenes, } \\
\text { polyols, phenols }\end{array}$ & $\begin{array}{l}\text { Dyestuff, plastic, fuel, solvent, drug, paint, } \\
\text { material applications, phenol-formaldehyde } \\
\text { resins, polyurethane foams, vanillin }\end{array}$ \\
\hline
\end{tabular}

Heterogeneous catalysis is a key and sustainable technology in modern chemical industry for the green chemical conversion of

124 lignocellulosic biomass, which plays an essential role in meeting the theoretical, technical, and economic challenges for biomass updating (Sudarsanam et al. 2019; Sudarsanam et al. 2018). Many researchers have reviewed the most representative examples and the recent achievements in the field of catalytic conversion of lignocellulosic biomass for the production of valuable products (Cao et al. 2019; Chio et al. 2019; Shivhare et al. 2021; Wong et al. 2020). Similarly, this paper attempts to summarize and review the recent research progress in different heterogeneous catalytic processes for the conversion of lignocellulosic polysaccharides (cellulose and hemicellulose) into a vast majority of commodity chemicals and potential fuels.

\section{Isolation of the lignocellulosic fractions}

Lignocellulose, as the major constituent of plant cell walls, is a complex composite which consists of cellulose, hemicellulose and lignin. These biopolymers are bound together in a very unique architecture by

139 long evolutionary process which brings huge biodiversity from the 140 molecular to the macroscopic level. As shown in Fig.2, these biopolymers 
are hierarchically organized. Specifically, cellulose and hemicellulose are macromolecular polymers linked by sugar units through glycosidic bonds, while lignin is a three-dimensional biological macromolecule composed of a large number of benzene rings. Hemicellulose and lignin are covalently linked to form a complex matrix structure in which cellulose is embedded (Imman et al. 2021). Although lignocellulosic biomass is attractive due to its inexpensiveness and abundance as a raw material, it has to be decomposed into individual components in order that it can be effectively treated by specific refining strategies (Zhang et al. 2021a). Isolation of the lignocellulosic biomass fractions is a difficult process started with pretreatment which is intended as a means of isolating the three components from depolymerization in subsequent heterogeneous catalytic steps. In general, this objective is achieved by the deconstruction of the complex matrix composed of lignin and hemicellulose in lignocellulose (Jusner et al. 2021; Rajak et al. 2021). Compared with one-pot deconstruction of whole lignocellulose (Sun et al. 2018b; Tian et al. 2022; Xia et al. 2016; Liao et al. 2020), emerging strategies are introduced to directly isolate components from lignocellulose to obtain tailor-made fractions through and for catalysis, thereby capitalizing on the full potential of catalysis in the refinement of lignocellulosic fractions into chemicals and fuels (Renders et al. 2018). 


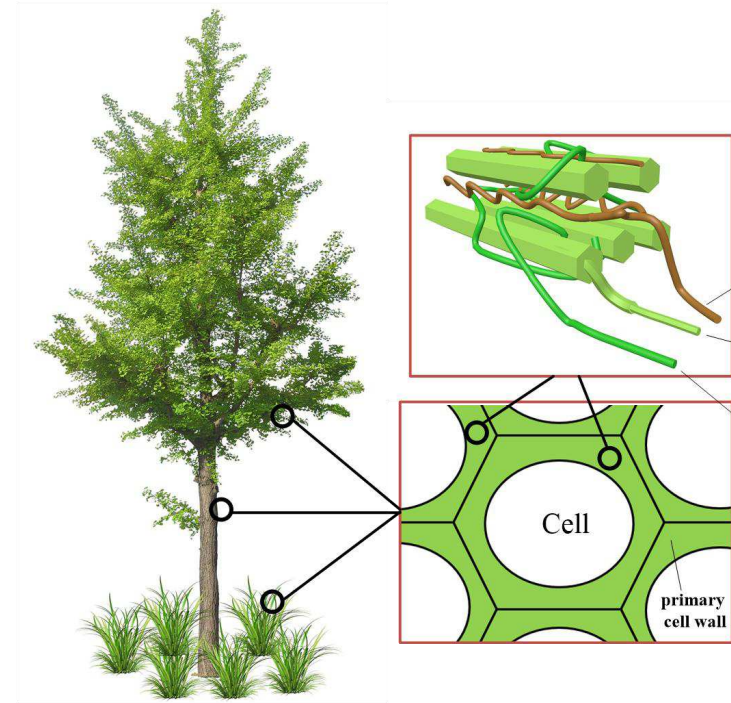

Fig. 2. Interaction of cellulose, hemicellulose and lignin in the cell wall of lignocellulosic biomass

Several technologies for isolating the three components of lignocellulose from each other were reported (Renders et al. 2018; Schutyser et al. 2018; Yang et al. 2017). For example, Schüth's group developed a solvent-free process using mechanocatalysis as a powerful methodology for the deep depolymerization of lignocellulose. This process acts as a platform for the fractionation of lignocellulose through the saccharification of the oligosaccharides (Käldström et al. 2014b). More than $90 \%$ yield of cellulose and hemicellulose can be obtained in the form of sugars (glucose and xylose) from beechwood, pinewood and sugarcane bagasse, meanwhile the sulfur-free lignin precipitates were also obtained (Käldström et al. 2014a). In addition, Leitner's group reported a one-step fractionation method to extricate the cellulose pulp, soluble hemicellulose monosaccharides and lignin from lignocellulosic material in a biphasic system. In the so-called "organocat process", lignin is 
selectively solvolyzed and hemicellulose is catalyzed by oxalic acid at mild temperatures $\left(80-140^{\circ} \mathrm{C}\right)$. As this process is performed in a biphasic system (water and 2-methyltetrahydrofuran), lignin fragments extracted by the organic solvent is directly separated from water-soluble hemicellulose sugars in the aqueous phase and cellulose solid (vom Stein et al. 2011).

Welton and co-workers have introduced protic ionic liquid (IL) 1-butylimidazolium hydrogen sulfate for the removal of the lignin and hemicellulose from the lignocellulosic matrix. IL, characterized by the properties of good solubility and acid sites, shows the ability to decompose and dissolve lignin and hemicellulose. Cellulose- rich pulp is left behind as residue. Importantly, the addition of water to the IL liquor leads to the precipitation of lignin (Verdía et al. 2014). During the isolation process, the utilization of acid and high temperatures generally results in severe and nonreversible condensation between lignin fragments and soluble hemicellulose sugars, which dramatically limits the further upgradation of lignocellulose. To solve such problems, Luterbacher's group presented a strategy to restrict the formation of interunit carbon-carbon bonds via the addition of formaldehyde during lignin extraction process. In this process, the formaldehyde prevented the condensation of lignin fragments by the formation of 1,3-dioxane structures with lignin side-chain hydroxyl groups. Moreover, cellulose, 
201 hemicellulose, and lignin were effectively separated for consequent 202 refinery (Shuai et al. 2016).

\section{Transformation of lignocellulosic polysaccharides}

\subsection{Cellulose transformation}

As a kind of supermolecule, cellulose is formed by anhydroglucose units with $\beta-1,4$-glycosidic linkages. In many cases, hydrolyzation of

207 cellulose to glucose with glucoside bond broken is perceived as a 208 necessary first step. Then, the glucose is further refined into various 209 platform chemicals and value-added products on the catalytic basis 210 (Rinaldi \& Schuth, 2009; Zeng \& Pan, 2020). In recent years, the direct

211 conversion of cellulose to fine chemicals has received extensive 212 attentions from the researchers. These fine chemicals are the precursors 213 for the products with higher value and liquid fuels. Fig. 3 illustrates the 214 various catalytic conversion pathway of cellulose via one-pot or multiple 215 step models, including hydrolyzation (Glucose), selective oxidation 216 (gluconic acid, formic acid, Levulinic acid), dehydration 217 (5-Hydroxymethylfurfuran and Levulinic acid), and 218 hydrogenation/hydrogenolysis (sorbitol, ethlyene glycol, 1,2-propylene 219 glycol and ethanol). 


\subsubsection{Hydrolyzation}

In general, cellulose can hardly be hydrolyzed in water due to its supramolecular crystal structure. Likewise, the hydrolyzation of cellulose usually involves the utilization of Brønsted acids as catalysts or severe condition $\left(25 \mathrm{MPa}, 320-400{ }^{\circ} \mathrm{C}\right)$ without catalyst (Rinaldi \& Schuth, 2009). Recent researches for acid-catalyzed hydrolysis of cellulose by cleaving glycosidic bonds are implemented through homogeneous and heterogeneous processes. Compared with homogeneous catalysts, heterogeneous solid acid catalysts for cellulose hydrolyzation have aroused increasing interest due to its inexpensiveness, reusability, controllable performance and minimization of corrosion (Tyufekchiev et al. 2018; Zeng \& Pan, 2020). Therefore, the rapid development of

234 recyclable solid acids has the potential to replace the unrecyclable liquid 235 acid catalysts in cellulose hydrolysis process (Geboers et al. 2011b; Lin \& George, 2009). 
238 Brønsted solid acids, such as sulfonated solid acid (nafion, amberlyst,

$239-\mathrm{SO}_{3} \mathrm{H}$ functionalized amorphous carbon or mesoporous silica), zeolite 240 (H-form zeolites), metal oxide $\left(\gamma-\mathrm{Al}_{2} \mathrm{O}_{3}\right)$, heteropoly acid and other 241 materials. In the meantime, their catalytic performances have been 242 explored on the cellulose hydrolysis (Hu et al. 2015; Huang \& Fu, 2013).

243 With solid acid catalysts, the typical hydrolytic product, such as glucose 244 can be produced. However, in most cases, the yields of the desired 245 products are quite low over solid catalysts due to the lacked catalytic 246 activity compared with liquid acid catalysts. Therefore, a longer reaction 247 time is needed to achieve the high yield of glucose.

248 Generally, cellulose hydrolysis with the breaking of glycosylic 249 bonds is catalyzed by the hydrogen cations $\left(\mathrm{H}^{+}\right)$ionized from the splitting 250 of water molecules on the surface of solid acid catalyst. Moreover, the 251 catalytic activity of catalysts increases with the decrease of the 252 deprotonation enthalpy (DPE) of water (Shimizu et al. 2009). Thus, the 253 catalyst with stronger Brønsted acidity is more beneficial to the catalytic 254 hydrolysis of cellulose. In that case, more water molecules can be split 255 into hydrogen cations $\left(\mathrm{H}^{+}\right)$and hydroxide anions $\left(\mathrm{OH}^{-}\right)$, and the $\mathrm{H}^{+}$ 256 attacks the oxygen atom in the 1,4- $\beta$-glycosidic linkage of cellulose. 257 Therefore, to some extent, the amount of water in the hydrolysis system 258 has an impact on the cleavage of $\beta-1,4$-glycosidic linkages and 
260 formation of glucose (Fig. 4). Additionally, cellulose hydrolysis over

261 solid acid catalysts under mild catalytic condition has been proved to be

262 beneficial to the production of glucose without deep degradation (Girisuta 263 et al. 2007).

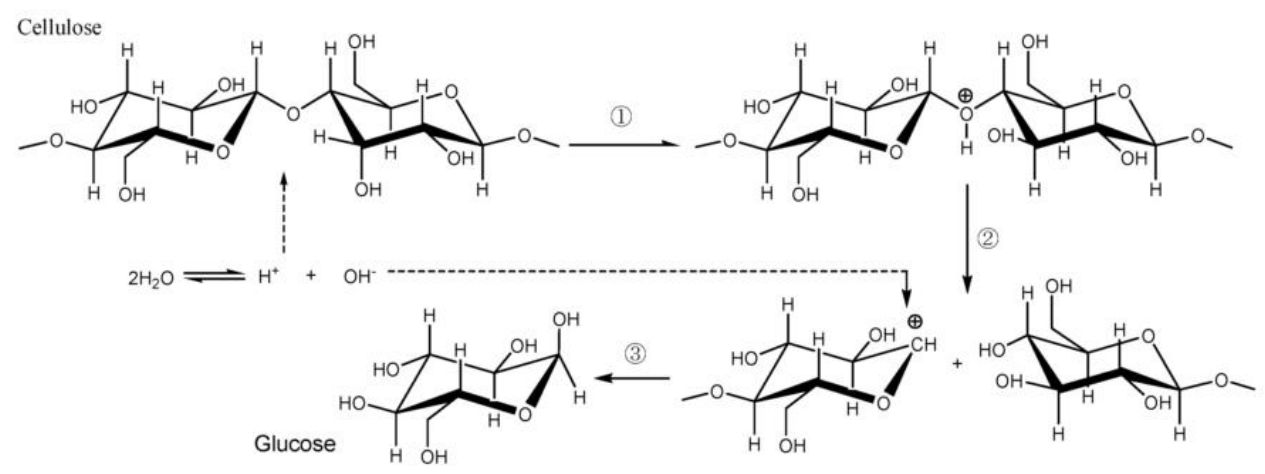

Fig. 4. Proposal mechanism of breakage of 1,4- $\beta$-glycosidic bonds and formation of glucose in the hydrolysis of cellulose.

Among the series of solid acid catalysts, sulfonated activated carbon (SAC) has shown excellent catalytic activity in cellulose hydrolyzation (Konwar et al. 2019). Almost simultaneously, Onda's group and Hara's group reported the SAC material in 2008. The former obtained a remarkably high glucose yield of $40.5 \%$ with the selectivity higher than 90\% (Onda et al. 2009; Onda et al. 2008). According their report, the SAC which grafted $-\mathrm{SO}_{3} \mathrm{H}$ functional groups was characterized by the singularly catalytic properties of strong acidity, hydrophobic planes on its surfaces, and high hydrothermal stability. While the latter identified that the hydrolysis of cellulose over SAC catalyst in water even showed a much lower activity energy $(110 \mathrm{KJ} / \mathrm{mol})$ compared with that in dilute 
$\mathrm{H}_{2} \mathrm{SO}_{4}$ solution $(170 \mathrm{KJ} / \mathrm{mol})$. The reason is that a strong affinity between $\beta$-1,4-glycosidic bonds of cellulose and SAC surfaces accelerated the activation of cellulose molecules. (Suganuma et al. 2008)

Pan's group developed a novel cellulase-mimetic solid catalyst, i.e., sulfonated chloromethyl polystyrene resin $\left(\mathrm{CP}-\mathrm{SO}_{3} \mathrm{H}\right)$ for the hydrolysis of cellulose. $\mathrm{CP}-\mathrm{SO}_{3} \mathrm{H}$ contained $-\mathrm{Cl}$ groups and $-\mathrm{SO}_{3} \mathrm{H}$ groups are taken as the cellulose-binding sites and the acidic sites, respectively, for catalytic cleavage of glycosidic bonds. With $\mathrm{CP}-\mathrm{SO}_{3} \mathrm{H}$ as the catalyst, raw material of microcrystalline cellulose could be hydrolyzed into glucose with the yield of $93 \%$ at $120{ }^{\circ} \mathrm{C}$ within 10 hours (Shuai \& Pan, 2012). Hu's group proposed a new one-pot synthetic method to immobilize the phosphotungstic acid (HPW) as the acidic active sites into ordered mesoporous silica (OMS). This co-condensation technique thickened the pore wall of the HPW/OMS material while retaining its highly ordered mesoporous structure. Employing heterogeneous HPW/OMS material as the catalyst, the conversion of cellulose reached $94.1 \%$ with $61.2 \%$ yield of reducing sugars (TRS) in $[\mathrm{BMIm}] \mathrm{Cl}$ at $140{ }^{\circ} \mathrm{C}$ for $4 \mathrm{~h}$. In addition, the solid acid catalyst was high in hydrothermal stability and excellent in recycling performance (Yu et al. 2021). Cui's group designed the temperature-responsive HCl-releasing catalysts for the improvement of mass transfer efficiency between heterogeneous catalyst and solid cellulose particles. This kind of catalyst exhibits a unique characteristic 
which can release $\mathrm{HCl}$ into aqueous phase for the homogeneous hydrolysis reaction of cellulose, and the released $\mathrm{HCl}$ can be immobilized and reused in mesoporous $\mathrm{N}$-doped carbon materials via simple cooling process after reaction. The novel catalyst system provided a total TRS yield of $81.1 \%$ and $61.1 \%$ glucose yield, respectively after the reaction under $220^{\circ} \mathrm{C}$ for 60 min with excellent catalytic stability (Wang et al. 2020d).

Through the systematic evaluation of the reported synthetic catalysts, valuable information and clues can be obtained for further design and preparation of a class of effective solid acid catalysts for catalytic hydrolysis of cellulose by adjusting their physical structures, such as specific surface area and pore size, as well as the active functional groups, such as grafted acid centers and adsorption sites to meet the demands of catalytic hydrolysis and even subsequent coupling reaction.

\subsubsection{Dehydration}

5-Hydroxymethylfurfural (5-HMF) derived from biomass has shown the potential for applications as a versatile platform in chemical industry production process. It can be refined to access 12 important furan derivatives and nonfuranic compounds through oxidation and hydrogenation reaction (van Putten et al. 2013). Cellulose conversion for 5-HMF production is currently a hotspot of both academic and commercial research. According to the researches, the chemical 
conversion of cellulose consists of three steps: (1) an initial hydrolysis process to convert cellulose into glucose; (2) further isomerized process to turn glucose into fructose; (3) chemical transformation of resulted fructose into 5-HMF (Fig. 5).

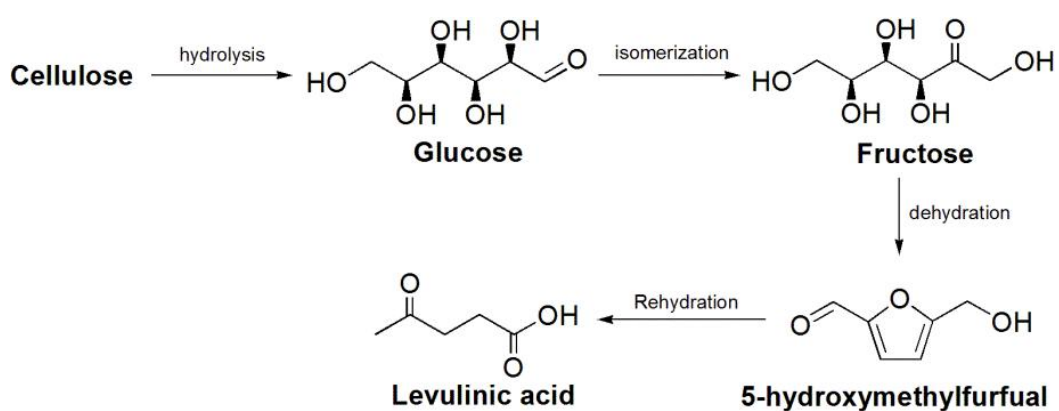

Fig. 5. Conversion of cellulose into 5-HMF and LA

Direct conversion of cellulose into HMF over heterogeneous catalysts can be conducted in different solvent systems and with various heterogeneous catalysts ( $\mathrm{Li}$ et al. 2018; Wen et al. 2019). Laosiripojana's group reported simultaneous hydrolysis/dehydration reactions of lignocellulosic material under hot compressed water (HCW) condition with the presence of $\mathrm{TiO}_{2}-\mathrm{ZrO}_{2}$ catalyst prepared by coprecipitation method. The yield of 5 -HMF of $8.6 \%$ could be obtained at $573 \mathrm{~K}$ and the pressure of $34.5 \mathrm{MPa}$ (Chareonlimkun et al. 2010). Wang's group employed heterogeneous $\mathrm{Cr}\left[(\mathrm{DS}) \mathrm{H}_{2} \mathrm{PW}_{12} \mathrm{O}_{40}\right]_{3}$, Brønsted-Lewis-surfactant-combined heteropolyacid as a stable and recyclable catalyst for 5-HMF production from cellulose. It proved that dodecyl sulfate in the catalyst could solubilize the cellulose, and enable better adsorption and interaction between cellulose and heteropolyacid catalyst, with which $77 \%$ of cellulose was hydrolyzed for the yield of 
HMF (423 K, 2h) of 52.7\% (Zhao et al. 2011). Wang's group synthesized a series of water-tolerant porous niobium phosphate solid acid catalysts 344 by tuning their surface acidity and the ratios between Brönsted and Lewis mesoporous carbon which was functionalized with benzenesulfonic acid

363 group as Brønsted acid sites. By the reaction in $\gamma$-valerolactone 
(GVL)- $\mathrm{H}_{2} \mathrm{O}$ system at $130{ }^{\circ} \mathrm{C}$ for $20 \mathrm{~min}$., the yield of 5-HMF derived 365 from cellulose reached $22.5 \%$ (Huang et al. 2018). Gromov's group prepared Sibunit carbon material which oxidized by $\mathrm{HNO}_{3}$ and sulfonated by fuming $\mathrm{H}_{2} \mathrm{SO}_{4}$ for the hydrolysis-dehydration of cellulose under semi-flow condition. Over this oxidized-sulfonated carbon catalyst, $10 \%$ yield of 5-HMF could be produced at $200{ }^{\circ} \mathrm{C}$ under $25 \mathrm{MPa}$ water pressure within $4 \mathrm{~h}$ (Aymonier et al. 2021). Gromov's group prepared Sibunit carbon material which was oxidized by $\mathrm{HNO}_{3}$ and sulfonated by fuming $\mathrm{H}_{2} \mathrm{SO}_{4}$ for the hydrolysis-dehydration of cellulose under semi-flow condition. Based on this oxidized-sulfonated carbon catalyst, the yield of 5-HMF of $10 \%$ could be obtained at $200{ }^{\circ} \mathrm{C}$ and under the temperature-responsive $\mathrm{HCl}$-releasing catalysts for 5-HMF production, with these catalysts, $96.4 \%$ of cellulose was converted into 5-HMF with 378 the yield of $52.6 \%$ in $\mathrm{MIBK} /$ water biphasic system after reacting at $220^{\circ} \mathrm{C}$ for $80 \mathrm{~min}$ (Wang et al. 2020c). Compared with the case using glucose and fructose as feedstock, the direct conversion of cellulose into 5-HMF is more challenging because 382 the additional hydrolyzation and isomerization steps must be implemented prior to fructose dehydration. These multistep processes 384 often result in poor 5-HMF yields in aqueous phase system, as shown in the following aspects. Firstly, in general, glucose isomerization occurs at 
386 the temperature of $100-120{ }^{\circ} \mathrm{C}$, while the temperature required for 387 fructose dehydration is above $120{ }^{\circ} \mathrm{C}$. This significant temperature 388 variation may lead to the production of humins as byproducts synthesized 389 from the products of catalytic sugar transformations, such as furfural, 390 formaldehyde, formic acid, and levulinic acid. Secondly, 5-HMF shows 391 poor stability, especially in the aqueous phase system due to the fact that 392 it can be easily hydrolyzed and condensed into byproducts. Therefore, the 393 improvement of efficiency in HMF production from cellulose drives the 394 quest for more active catalysts and the regulation of the reaction 395 conditions for by-products reduction.

396 Over decades of study, the researchers have endeavored to develop 397 the efficient heterogeneous catalysts for the synthesis of levulinic acid 398 from cellulose (Boonyakarn et al. 2019; Weingarten et al. 2012; Zunita et 399 al. 2020). Fu's group synthesized a novel heterogeneous catalyst of 400 sulfonated chloromethyl polystyrene $(\mathrm{CP})$ resin $\left(\mathrm{CP}-\mathrm{SO}_{3} \mathrm{H}-1.69\right)$ with 401 sulfonic-acid groups and chlorine groups $(-\mathrm{Cl})$ as the acid centers and 402 cellulose-binding sites, respectively. With this catalyst, the yield of $65.5 \%$ 403 for levulinic acid was obtained by in the conversion of microcrystalline 404 cellulose (Zuo et al. 2014). Wu's group designed a hierarchically porous 405 titanium-silica zeolite (ETS-10) loaded with highly dispersed Ni catalyst 406 with moderate Lewis acidic centers and hierarchical pores, which was 407 revealed to be beneficial to the activation of the reaction substrates and 
mass transfer process. The significantly high yield $(91.0 \%)$ of levulinic acid was achieved with full conversion of cellulose over the impressive Ni-HMETS-10 catalyst under mild reaction condition (Xiang et al. 2017). In recent years, researchers are constantly developing new heterogeneous catalytic technologies to produce levulinic acid from cellulose by introducing suitable solvent system to improve the interaction between cellulose and the solid acid catalyst, and tuning pore structure and acid sites (Ma et al. 2021; Sun et al. 2018a).

\subsubsection{Hydrogenation/Hydrogenolysis}

The direct conversion of cellulose through hydrogenation and hydrogenolysis processes provides access to a diverse range of chemical platforms, i.e., $\mathrm{C}_{6}$ polyols (sorbitol and mannitol), $\mathrm{C}_{3}$ polyol (1,2-Propylene glycol), and $\mathrm{C}_{2}$ alcohols (ethylene glycol and ethanol). Among them, sorbitol is listed as one of the 12 most important platform compounds derived from biomass by the U.S. Department of Energy (Luo et al. 2020; Tindall et al. 2021). With the rapid development of chemical industry, biomass derived alcohols become more important gradually, which has a wide range of applications in pharmaceutical, food, energy, chemical, agrochemical and other fields, as well as in the scientific research (Kumar et al. 2020; Lee, 2015).

As shown in Fig. 6, the conventional route of the heterogeneous synthesis of hexitols (sorbitol/mannitol) from cellulose consists of two 
steps: (1) cellulose is firstly hydrolyzed into glucose by $\mathrm{H}_{3} \mathrm{O}^{+}$ions, which are formed by $\mathrm{H}^{+}$(from acid ionization with high temperature water and $\mathrm{H}_{2}$ overflow) combined with water molecules; (2) glucose is subsequently hydrogenated into sorbitol over the hydrogenation catalyst, and fructose, derived from glucose isomerization, into mannitol.

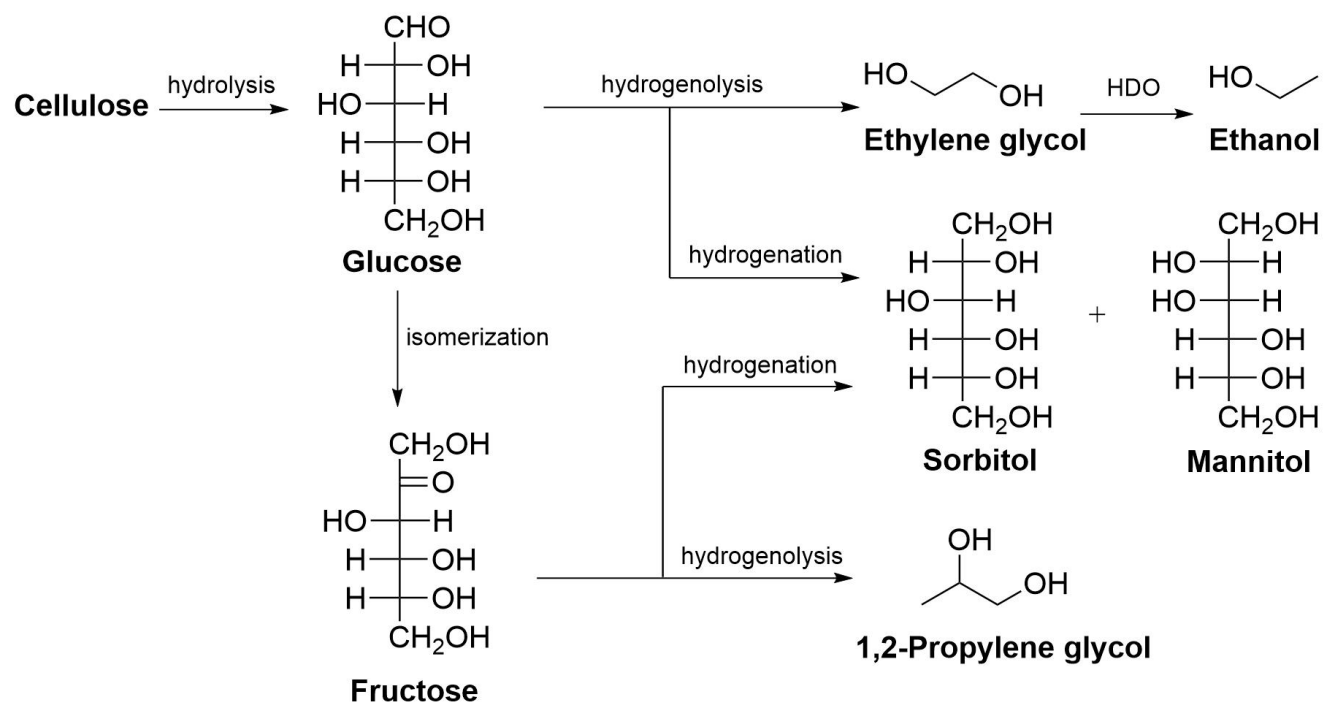

Fig. 6. Reaction pathway of one-pot cellulose conversion to polyols over biofunctional catalysts

The reactions coupling hydrolyzation with hydrogenation to produce sorbitol and mannitol have been widely studied (Rey-Raap et al. 2019; Ribeiro et al. 2017; Ruppert et al. 2012). These reactions are preceded by a hydrolysis process to depolymerize cellulose into glucose and fructose, and followed by hydrogenation to obtain the corresponding C6 polyols. It is known that liquid water is available to form $\mathrm{H}^{+}$ions capable of conducting acid-catalyzed reaction at elevated temperature (above $473 \mathrm{~K}$ ). Therefore, Liu's group reported an efficient method combing hydrolysis using $\mathrm{H}^{+}$ions which were reversibly formed in situ in hot water with 
instantaneous hydrogenation on $\mathrm{Ru} / \mathrm{C}$ for the conversion of cellulose into hexitols (Luo et al. 2007). Ma's group used amorphous zirconium phosphate catalyst as hydrolyst and commercial $\mathrm{Ru} / \mathrm{C}$ as hydrogenation catalyst for hexitols production. With this catalyst, the yield of $63.5 \%$ for $\mathrm{C}_{6}$ alditols was obtained from microcrystalline cellulose at $488 \mathrm{~K}$ for 1.5 h. Moreover, they investigated the ball-milled cellulose as the feedstocks, and the yield of sugar alcohols can be reached as high as $90.3 \%$ at $463 \mathrm{~K}$ for $2.5 \mathrm{~h}$ (Liao et al. 2014a; Liao et al. 2014b).

For coupling method, it's worth noting that the optimized balance between two catalytic functions of hydrolyzation with hydrogenation is essential for an effective and selective catalytic hydrolytic hydrogenation system. Cellulose can be hydrolyzed by using the acid catalyst, which is followed by a fast metal-catalyzed hydrogenation of the resulted glucose to hexitols. However, the coupling reaction mixed with different catalysts usually brings inevitable issues of separation. A one-pot combined approach has been developed for the direct conversion of cellulose into sorbitol and mannitol based on bifunctional catalysts. The "bifunctional" catalysts are generally composed of metal ingredients $(\mathrm{Ru}, \mathrm{Pt}, \mathrm{Ni})$ supported by Brønsted acidic zeolites (H-USY, H-ZSM-5, H mordernite) and carbon materials (Deng et al. 2014; Yabushita et al. 2014), on which the glucose and fructose are generated in situ by acidic hydrolysis of cellulose and then converted into polyols by hydrogenation catalyst. 

utilization of $\mathrm{Pt} / \gamma-\mathrm{Al}_{2} \mathrm{O}_{3}$ catalyst in hydrolytic hydrogenation of the 471 cellulose for hexitols production. Cellulose was firstly catalyzed by the 472 acidic sites into glucose, and the $\mathrm{C}=\mathrm{O}$ group in glucose was promptly reduced by Pt to form sorbitol. The hydrolysis of cellulose to glucose is a rate-determining step because the reduction of glucose gave an almost stoichiometric amount of sorbitol over the Pt catalyst. Accordingly, a total over $\mathrm{Pt} / \gamma-\mathrm{Al}_{2} \mathrm{O}_{3}$ catalyst (Fukuoka \& Dhepe, 2006).

Sels' group proposed a nickel catalyst supported by carbon nanofiber yield is considered to be based on the pear-shaped Ni nanoclusters on the tips of the carbon nanofibers, which effectively restrains the undesired C-C and C-O bond breaking (Van de Vyver et al. 2010; Van de Vyver et al. 2012). However, cellulose and cello-oligomers are unable to be effectively depolymerized into glucose before hydrogenation by the metal sites during the reaction process, resulting in a finite hexitols yield. After that, they provided $\mathrm{Ru}-$ loaded zeolites $(\mathrm{Ru} / \mathrm{H}-\mathrm{USY})$ catalyst accompanied by with trace amounts of mineral acid $(\mathrm{PH}=3)$ for hydrolytic hydrogenation of cellulose. A much lower soluble acid concentration is sufficient for the completion of cellulose conversion, leading to an 
excellent yield ( $>90 \%$ ) of hexitols (Geboers et al. 2011a). The research emphasized the advantages of the multifunctional activity for the direct conversion of cellulose into hexitols. However, physicochemical and catalytic data showed that the rate-determining step lies in the hydrolysis of cellulose to glucose, depending on the surface acidity of catalysts. Therefore, it is important to achieve a balance between the hydrolysis and hydrogenation step without excessive dehydration.

Ethylene glycol (EG) and 1,2-propylene glycol (PG) produced by industrial petrochemical route are important organic compounds and platform chemicals used in industrial processes of energy, plastics, automobiles, etc. The direct conversion of cellulose into EG and PG has been regarded as a new type high-value utilization of biomass. Zhang's group first proposed the utilization of $\mathrm{Ni}-\mathrm{W}_{2} \mathrm{C} / \mathrm{AC}$ catalyst for one-pot synthesis of EG from cellulose, and achieved the yield of $61 \%(518 \mathrm{~K}, 6$ MPa of $\mathrm{H}_{2}$ for $30 \mathrm{~min}$ ) ( $\mathrm{Ji}$ et al. 2008). It was revealed that nickel components promoted the hydrogenation by activating hydrogen, and the tungsten active components are available to catalyze the substrate by selectively breaking its $\mathrm{C}-\mathrm{C}$ bonds, such as retro-aldol reaction ( $\mathrm{Li}$ et al. 2012). Liu's group investigated the mixed $\mathrm{Ru} / \mathrm{C}+\mathrm{WO}_{3}$ catalysts for cellulose hydrogenolysis, and a total yield of $56.3 \%$ for diols (EG: $48.9 \%$, PG: $7.4 \%$ ) was obtained. $\mathrm{WO}_{3}$ crystallite played two roles in this reaction, namely, the acceleration of the hydrolysis of cellulose into sugars and the 
513 selective cleavage of the $\mathrm{C}-\mathrm{C}$ bonds in these sugars. $\mathrm{Ru} / \mathrm{C}$ catalyst 514 promoted the hydrogenation of intermediates by activating hydrogen, 515 leading to the controllable synthesis of diols from cellulose (Liu et al. 516 2012). They further explored the product distribution in the hydrolytic 517 hydrogenolysis of cellulose using $\mathrm{Pt}-\mathrm{SnO}_{\mathrm{x}} / \mathrm{Al}_{2} \mathrm{O}_{3}$ catalyst. A significant 518 change in the distribution of polyols occurred with the $\mathrm{Sn} / \mathrm{Pt}$ atomic ratio 519 ranging largely from $0.1-3.8$ on $\mathrm{Pt}-\mathrm{SnO}_{\mathrm{x}} / \mathrm{Al}_{2} \mathrm{O}_{3}$ catalyst. When the $\mathrm{Sn} / \mathrm{Pt}$ 520 ratio exceeding 1.5 , higher selectivity to idols (e.g. EG, PG) could be 521 obtained compared with $\mathrm{Pt} / \mathrm{Al}_{2} \mathrm{O}_{3}$, which explained that the formation of crystalline Pt-Sn alloy led to the preferential conversion of cellulose into

523 idols (Deng \& Liu, 2013). A two-step thermochemical catalytic process 524 was adopted by Zhang's group to convert cellulose into EG, in which 525 methyle glycolate (MG) was firstly produced by using a physical mixture 526 of $\mathrm{WO}_{\mathrm{x}}$ and $\mathrm{CMK}-3$ as the catalyst, and then nearly and quantitatively 527 converted into $\mathrm{EG}$ over $\mathrm{Cu} / \mathrm{SiO}_{2}$ catalyst. The two-step method is able to 528 effectively suppress the coking of the intermediates, and improve the 529 yield of EG. However, cellulose depolymerization requires high 530 temperature and multi-step reaction conditions, resulting in a complex 531 and uneconomic process (Xu et al. 2017). In the previous researches, tungsten oxide is mainly used as the 533 catalyst support, and noble metal or base metal $\mathrm{Ni}$ is taken the active 534 species (Lv et al. 2020). On the one hand, the conversion efficiency is not 
high over such catalyst (for example, only about $80 \%$ conversion), on the other hand, considering the cost and catalyst stability, the catalysts of metal oxide supported by metal require the properties of low cost, high catalytic stability and conversion efficiency. Therefore, Zhang's group designed a simple and efficient process using weakly alkaline $\mathrm{Co} / \mathrm{CeO}_{\mathrm{x}}$ catalyst for one-pot conversion of cellulose into diols. The base metal Co catalysts supported by non-tungsten oxides as hydrogenation metals are characterized by simple structure, stable performance and high catalytic efficiency. Notably, a total yield of $89.1 \%$ for diols (EG: $55.2 \%$, PG: $33.9 \%$ ) was achieved in aqueous catalytic system over $10 \% \mathrm{Co} / \mathrm{CeO}_{\mathrm{x}}$ catalyst under relatively mild condition $\left(245^{\circ} \mathrm{C}, 3 \mathrm{MPa} \mathrm{H}_{2}, 6 \mathrm{~h}\right)$ ( $\mathrm{Li}$ et al. 2019a). Accordingly, one-pot catalytic conversion of cellulose into diols is a complex reaction network, which consists of hydrolysis, isomerization, retro-aldol-type fragmentation, hydrogenation, dehydrogenation, and thermal side reactions. The key factor for obtaining high yield of cellulosic idols lies in the balance among various catalytic steps to match the reaction rates (Zheng et al. 2017).

Ethanol $(\mathrm{EtOH})$ is regarded as an ideal fuel substitute for the reduction of the consumption of petroleum in the future. As a traditional technology, biological fermentation processes have been employed to produce ethanol, in which enzymes depolymerize cellulose into simple sugars, such as glucose, which is followed by fermentation and 
distillation. Nevertheless, the fermentation process suffers many problems, such as high cellulase price, long production cycle and many inhibiting factors in the reaction process. Chemical conversion method has the advantages of wide adaptability of raw materials, high production intensity and easy amplification, which is expected to break the bottleneck of the limit yield and concentration of EtOH produced by traditional biological fermentation. Consequently, one-pot production of EtOH directly from cellulose by chemical method provides an important direction for the development in recent year (Chu et al. 2021).

Since 2017, Zhang's group had provided a two-step cellulose-MG-EtOH route for the conversion of cellulose into ethanol. Methyle glycolate (MG), derived from cellulose in the first step, was converted into EtOH over $\mathrm{Cu} / \mathrm{SiO}_{2}$ catalyst at $280{ }^{\circ} \mathrm{C}$ with the selectivity of $50 \%$ and the total yield of $29 \%$ based on cellulose (Xu et al. 2017). Then, they improved the method into the one-pot production of cellulosic $\mathrm{EtOH}$ at the yield of $43.2 \mathrm{C} \%$ over a multifunctional $\mathrm{Mo} / \mathrm{Pt} / \mathrm{WO}_{\mathrm{x}}$ catalyst. It is identified that the formed ${ }_{x} \mathrm{OMo}-\mathrm{Pt}-\mathrm{WO}_{\mathrm{x}}$ interfacial structure succeeded in accelerating the speed of EG hydrogenolysis into ethanol (Yang et al. 2019). Shortly afterwards, the multi-functional catalysts of $\mathrm{H}_{2} \mathrm{WO}_{4}-\mathrm{Pt} / \mathrm{ZrO}_{2}$ and $\mathrm{Ru}-\mathrm{WOx} / \mathrm{HZSM}-5$ had been reported by Wang's and Zhang's group, which obtain the cellulosic EtOH yield of 32\% and 53.7\%, respectively (Li et al. 2019b; Song et al. 2019). To efficiently hydrolyze 
579 cellulose into glucose for the subsequent hydrogenation and 580 hydrogenolysis reactions, Ma's group introduced phosphoric acid $\left(\mathrm{H}_{3} \mathrm{PO}_{4}\right)$ 581 to assist $\mathrm{Ni@C}$ in one-pot efficient conversion of cellulose to $\mathrm{EtOH}$. 582 Moreover, $\mathrm{H}_{3} \mathrm{PO}_{4}$ interacts with glucose to form cyclic di-ester bonds, 583 promoting EtOH formation under the synergistic hydrogenation of $\mathrm{Ni} @ \mathrm{C}$. $58469.1 \%$ of EtOH yield (carbon mole basis), and reaching the concentration 585 of $8.9 \mathrm{wt} \%$ in this catalytic system (Liu et al. 2019). One-pot chemical 586 catalytic routes to $\mathrm{EtOH}$ from cellulose are considered as promising 587 pathways with growing interest, although the reaction networks are very 588 complex. The product selectivity thus plays a crucial role, and the key 589 factor lies in the balance among the major cascade catalytic reaction 590 steps.

The product distribution in hydrogenation/hydrogenolysis of cellulose is mainly controlled by the respective capacities of cellulose hydrolysis and glucose hydrogenation/hydrogenolysis. The catalysts with specific acid/metal site ratios should be developed for the regulation of the hydrolysis of cellulose and its hydrogenation/hydrogenolysis of glucose. In this manner, sugar alcohols (sorbitol and mannitol) and small

597 molecule alcohols (EG, PG and EtOH) can be prepared in a controlled 598 way.

\subsubsection{Selective oxidation}

The direct transformation of cellulose through selective oxidation 
601

602

603

604

605

606

607

608

609

610

611

612

613

614

615

616

pathway can provide a diverse range of organic acids, such as gluconic acid, lactic acid, levulinic acid and formic acid (Zhang \& Huber, 2018) (Fig.7), which exhibits widespread applications in the food, detergent, and pharmaceutical industries. Gluconic acid and lactic acid are produced commercially by the fermentation (enzymatic oxidation) of glucose, presenting problematic enzyme separation, waste water removal, and a narrow window of reaction conditions. There is hence an opportunity for the heterogeneously catalyzed routes. Selective oxidation of cellulose can be conducted by using anaerobic and aerobic methods.

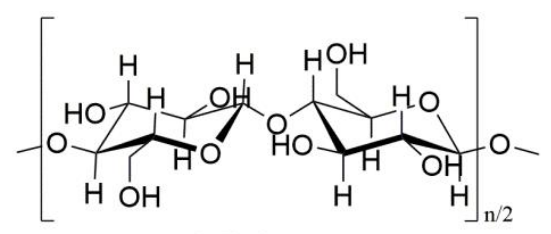

Cellulose

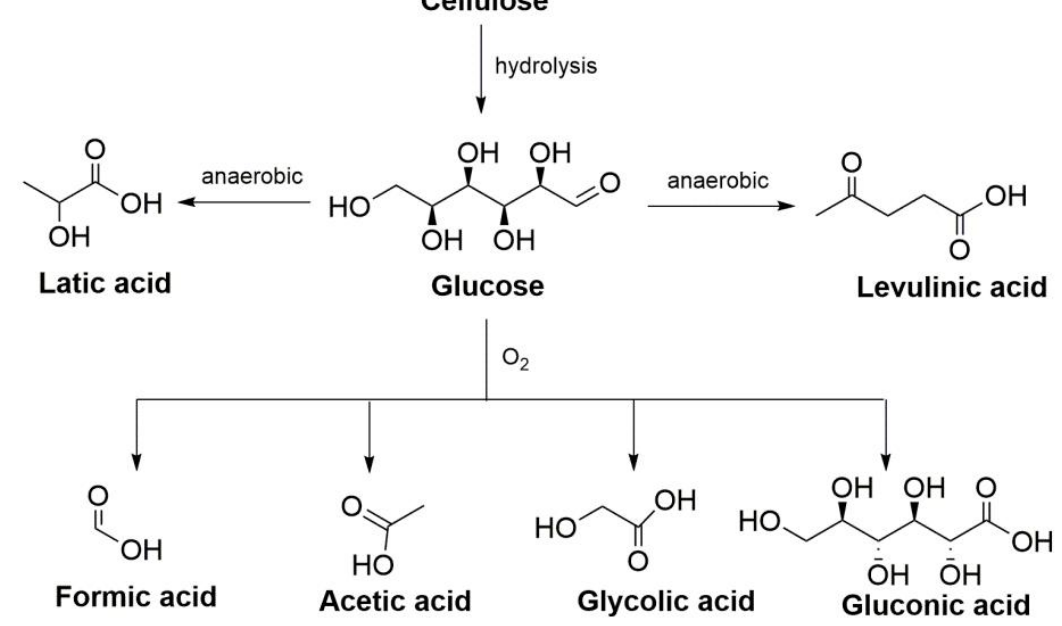

Fig. 7. Organic acids that can be produced form cellulose via glucose

For the current commercial production of gluconic acid, submerged fermentation method was used. The chemical conversion of cellulose into gluconic acid is a big challenge, and the reported works focused on its aerobic selective oxidation pathway. Synthesis of gluconic acid from cellulose has been generally achieved by using metal catalysts ( $\mathrm{Au}, \mathrm{Pd}, \mathrm{Pt})$ 
supported by carbon materials (carbon nanotube and mesoporous carbon) and heteropolyacid catalyst. Most of the research works mainly focused on the oxidative conversion of glucose and cellobiose into gluconic acid (Guo et al. 2019; Zhang et al. 2021b; Zhang et al. 2020), and few works are known for direct conversion of cellulose. Wang's group reported an $\mathrm{Au} / \mathrm{Cs}_{1.2} \mathrm{H}_{1.8} \mathrm{PW}_{12} \mathrm{O}_{40}$ catalyst for the transformation of cellulose into gluconic acid with the yield of $60 \%\left(418 \mathrm{~K}, 1.0 \mathrm{MPa} \mathrm{O}_{2}\right)$. Although $\mathrm{Au} / \mathrm{Cs}_{1.2} \mathrm{H}_{1.8} \mathrm{PW}_{12} \mathrm{O}_{40}$ showed decreased catalytic performance in the second run, a combined catalyst between $\mathrm{H}_{3} \mathrm{PW}_{12} \mathrm{O}_{40}$ and $\mathrm{Au} / \mathrm{Cs}_{1.2} \mathrm{H}_{1.8} \mathrm{PW}_{12} \mathrm{O}_{40}$ was reusable at least for 6 runs (An et al. 2012). Direct conversion of cellulose as the feedstocks should be encouraged for the production of gluconic acid through hydrolytic selectively oxidation process. Basically, this reaction system requires two successive steps, that is, the acid-catalyzed hydrolysis of cellulose into glucose promoted by acidic sites and the oxidation of resulted glucose by the metal particles.

Heterogeneous synthesis of lactic acid from cellulose involves a set of tandem steps, i.e., the hydrolysis of cellulose to glucose, the isomerisation of glucose to fructose, the retro-aldol condensation of fructose to $\mathrm{C} 3$ intermediates and the subsequent conversion of the $\mathrm{C} 3$ intermediates to lactic acid ( $\mathrm{Li}$ et al. 2016). Wang's group designed stable solid $\mathrm{Yb}(\mathrm{OTf})_{2}-\mathrm{SO}_{3}-\mathrm{SBA}-15$ catalysts to deal with the recycle issue of trifluoromethanesulfonic acid, and found that efficient conversion of 
639 cellulose to lactic acid was achieved by regulating the amount of $640 \mathrm{Yb}(\mathrm{OTf})_{3}$ immobilized on sulfo-functionalized SBA-15, and the yield of $64171.6 \%$ for lactic acid was obtained at 493K for $2 \mathrm{~h}$ (Wang et al. 2018). 642 Shi's group prepared the solid $\mathrm{Al}_{2}\left(\mathrm{WO}_{4}\right)_{3}$ catalyst to provide $\mathrm{Al}-\mathrm{OH}$ and $643 \mathrm{~W}=\mathrm{O}$ functional groups as the active sites, thereby enhancing the 644 hydrolytic oxidation of cellulose into lactic acid. Under the optimum 645 condition of $220{ }^{\circ} \mathrm{C}$ for $3 \mathrm{~h}$, the yield of $46 \%$ for lactic acid could be 646 produced based on the synergistic effect of the $\mathrm{W}=\mathrm{O}$ species and the 647 adjacent $\mathrm{Al}=\mathrm{OH}$ species in $\mathrm{Al}_{2}\left(\mathrm{WO}_{4}\right)_{3}$ (Shi et al. 2019) Wang's group 648 further reported the yttrium modified siliceous Beta zeolites for highly 649 efficient conversion of cellulose into lactic acid. It was demonstrated that 650 the dealumination operation suppressed the by-products (e.g. 5-HMF) in 651 the dehydration process and modification of yttrium increased Lewis 652 acidity amount for lactic acid production. In this regard, the yield of $65349.2 \%$ for lactic acid was obtained at $220{ }^{\circ} \mathrm{C}$ within 30 min (Ye et al. 654 2021).

655

656

657

658

659

660

\subsection{Hemicelulose transformation}

Hemicellulose is an amorphous heteropolymer composed of several different types of monosaccharides, such as xylose, arabinose, galactose, etc., which can be extracted from cell walls (Tian et al. 2022; Wang et al. 2021). Although the composition of hemicellulose fraction changes with the cell types and plant species, it typically contains large amounts of 
xylose, arabinose and pentose sugars commonly used as the starting materials for furans, polyols and their subsequent products (Fig. 8) (Sun et al. 2021).
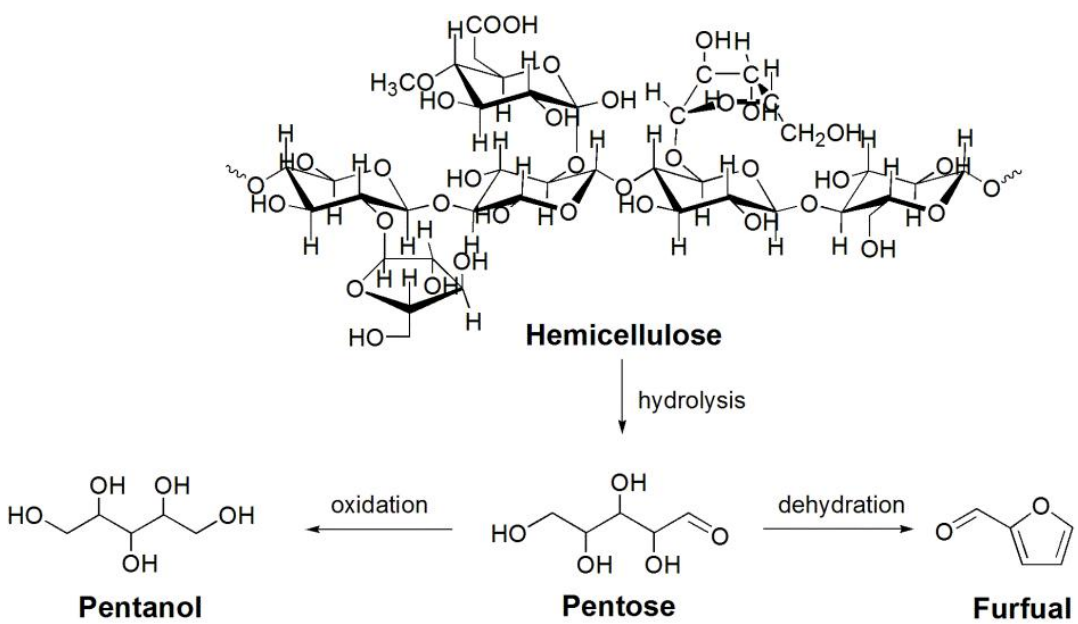

Fig. 8. The main catalytic conversion pathway of hemicellulose

Direct conversion of hemicellulose over heterogeneous catalysts is rarely reported due to its poor product selectivity. Fukuoka's group reported a combined hydrolytic hydrogenation process for the conversion of hemicellulose into arabitol over $\mathrm{Ru} / \mathrm{C}$ catalyst with the yield of $83 \%$ for arabitol at $155{ }^{\circ} \mathrm{C}$ for $24 \mathrm{~h}$. The observed product selectivity depends on the acidity and the carbonic structure used in the $\mathrm{Ru} / \mathrm{C}$ catalysts (Guha et al. 2011). Zhang's group converted hemicellulose and cellulose in woody biomass into a mixture of ethylene glycol and other diols using a $\mathrm{Ni}-\mathrm{W}_{2} \mathrm{C}$ catalyst, and obtained the total yield of $75.6 \%$ at $235{ }^{\circ} \mathrm{C}$ for $4 \mathrm{~h}$ (Li et al. 2012). Lin's group demonstrated that lactic acid could be produced from xylan, represented by hemicellulose using $\mathrm{ZrO}_{2}$ catalyst. It was revealed that the acid/base pairs on the surface of $\mathrm{ZrO}_{2}$ played a crucial role in facilitating the retro-aldol fragmentation of xylose, and the 
679

680

681

682

683

684

685

686

687

688

689

690

691

692

693

694

695

696 697 chemical platform products were reviewed in recently references (Gurbuz

698 et al. 2013; Zhang et al. 2016) .

699

700

molar yield of $30 \%$ for lactic acid was obtained at $200{ }^{\circ} \mathrm{C}$ for $40 \mathrm{~min}$ (Yang et al. 2015). Fan's group carried out cascade reaction for the integrate conversion of hemicellulose into $\gamma$-Valerolactone (GVL), in which hemicellulose first underwent hydrolyzation to ensure the dehydration for furfural over ZSM-5 catalyst. Subsequently, the formed furfural was transformed to $\mathrm{GVL}$ over $\mathrm{Au} / \mathrm{ZrO}_{2}$ catalyst combined with ZSM-5. At last, the yield of $61.5 \%$ for GVL based on hemicellulose was obtained at $120^{\circ} \mathrm{C}$ for $24 \mathrm{~h}$ (Zhu et al. 2016).

Hemicellulose is more readily hydrolyzed to sugars than cellulose mostly due to the amorphous and branched structures. Consequently, it is impossible for the optimization to maximize individual cellulosic glucose and hemicellulose sugar recovery in the same reaction system of lignocellulose. In general, the first step of the chemical conversion of hemicellulose is a depolymerization process in liquid acid media during the isolation process, as we mentioned previously in Section 2. Hemicellulose was extracted in the form of hexoses (e.g. xylose and arabinose) for further refinery to furfural, xylitol and other chemicals. The methods for converting the hexoses derived from hemicellulose to et al. 2013, Zhang et al. 2016).

\section{Future Perspectives}

All the current commercial chemicals are derived from 
petrochemical feedstocks. Despite the renewed interest and extensive researches in the development of lignocellulose biorefinery, no commercialized biofuels and bulk commodity chemicals are produced from lignocellulosic polysaccharides due to the economic and environmental considerations on low overall carbon yield and separation problems (Chandel et al. 2018). However, further conversion of lignocellulosic polysaccharides has great potential to deal with some knotty global problems, such as global warming, food crisis and environmental problems. Catalytic routes for lignocellulosic polysaccharides conversion to renewable chemicals and fuels will underpin the valorization of bio-derived feedstocks. The exploitation of new strategies for value-added platform chemicals and scale-up of these processes to produce bio-derived products at commercial scale is the objective of most researchers to work in high-valued utilization of lignocellulosic biomass. The development of the designs of new heterogeneous catalytic processes for biorefinery applications still represent a significant challenge requiring more advanced research and collaboration to across the interfaces between the following aspects:

1. Since the chemical components in the cell wall of lignocellulosic biomass can be regulated by using biological technology, the operations are necessary to be implemented on genetic engineering to increase the homogeneity of the polymer or the proportion of easily cleavable linkages 
in lignocellulosic biomass.

2. The complex nature of lignocellulosic biomass in the chemical composition and structure in cellulose, hemicellulose and lignin may result in much different reactivity, meaning that more efficient and green progress in the fractionation of lignocellulosic biomass should be conducted. Moreover, the optimal pretreatment has to be done for the reduction of the energy activity of lignocellulosic fractions, for example, destroying the crystal structure of cellulose and decreasing lignin repolymerization.

3. Heterogeneous catalysis is a key technology for the valorization of lignocellulosic polysaccharides (cellulose in particular) and lignin. The development of the advanced catalysis technology facilitates the rational design of robust catalysts with specific physical structures, such as surface area and pore size, as well as the active functional groups, such as grafted acid centers and adsorption sites, solvent systems and metallic sites with optimal acid/metal site ratios for selective transformation of lignocellulosic components.

4. Further mechanistic analysis has become increasingly important in elucidating new reaction pathways and developing associated kinetic models to guide the design process, and maintain the catalyst performance. Moreover, it will also play a significant role in understanding the distinction in product selectivity, and developing the 
catalysts suitable for commercial applications of these processes.

5. To date, most of the catalytic methods used for lignocellulosic conversion belong batch reactions, while consecutive reaction is more suitable for industrial production, which is mainly because that it is almost insoluble in most solvents (cellulose in particular). In this context, effective pretreatment and catalytic techniques should be developed, which presents another focus for the production of fine chemicals in biorefineries.

\section{Acknowledgments}

This research was financial support by the Natural Science Foundation of Hunan Province, China (Grant No. 2020JJ5159), Scientific Research Fund of Hunan Provincial Education Department (18C0354), Beijing Key Laboratory of Enze Biomass Fine Chemicals.

\section{Declarations}

Conflicts of interest: The authors confirm that this article content has no conflict of interest.

Ethical approval: This article does not contain any studies with human participants or animals performed by any of the authors.

\section{References}

Alonso DM, Bond JQ, Dumesic JA (2010) Catalytic conversion of biomass to biofuels. Green Chem 12(9): 1493-1513.

Alonso DM, Hakim SH, Zhou S, Won W, Hosseinaei O, Tao J et al (2017) Increasing the revenue from lignocellulosic biomass: maximizing feedstock utilization. Sci Adv 3(5): e1603301. 
Alper K, Tekin K, Karagöz S, Ragauskas AJ (2020) Sustainable energy and fuels from biomass: a review focusing on hydrothermal biomass processing. Sustain Energ Fuels 4(9): 4390-4414.

An D, Ye A, Deng W, Zhang Q, Wang Y (2012) Selective conversion of cellobiose and cellulose into gluconic acid in water in the presence of oxygen, catalyzed by polyoxometalate-supported gold nanoparticles. Chem Eur J 18(10): 2938-2947.

Atanda L, Konarova M, Ma Q, Mukundan S, Shrotri A, Beltramini J (2016) High yield conversion of cellulosic biomass into 5-hydroxymethylfurfural and a study of the reaction kinetics of cellulose to HMF conversion in a biphasic system. Catal Sci Technol 6(16): 6257-6266.

Atanda L, Shrotri A, Mukundan S, Ma Q, Konarova M, Beltramini J (2015) Direct production of 5-hydroxymethylfurfural via catalytic conversion of simple and complex sugars over phosphated $\mathrm{TiO}_{2}$. ChemSusChem 8(17): 2907-2916.

Fukuoka A, Dhepe PL (2006) Catalytic conversion of cellulose into sugar alcohols. Angew Chem Int Ed 118(31): 5285-5287.

Aymonier C, Gromov NV, Taran OP, Parmon VN (2021) Hydrolysis-dehydration of cellulose to glucose and 5-hydroxymethylfurfural over Sibunit solid acid carbon catalysts under semi-flow conditions. Wood Sci Technol 55(3): 607-624.

Girisuta B, Janssen LPBM, Heeres HJ (2007) Kinetic study on the acid-catalyzed hydrolysis of cellulose to levulinic acid. Ind Eng Chem Res 46: 1696-1708.

Boonyakarn T, Wataniyakul P, Boonnoun P, Quitain AT, Kida T, Sasaki M et al (2019) Enhanced levulinic acid production from cellulose by combined brønsted hydrothermal carbon and Lewis acid catalysts. Ind Eng Chem Res 58(8): 2697-2703.

Cao Y, Chen SS, Zhang S, Ok YS, Matsagar BM, Wu KC et al (2019) Advances in lignin valorization towards bio-based chemicals and fuels: Lignin biorefinery. Bioresour Technol 291: 121878.

Chandel AK, Garlapati VK, Singh AK, Antunes FAF, da Silva SS (2018) The path forward for lignocellulose biorefineries: Bottlenecks, solutions, and perspective on commercialization. Bioresour Technol 264: 370-381.

Chareonlimkun A, Champreda V, Shotipruk A, Laosiripojana N (2010) Catalytic conversion of sugarcane bagasse, rice husk and corncob in the presence of $\mathrm{TiO}_{2}, \mathrm{ZrO}_{2}$ and mixed-oxide $\mathrm{TiO}_{2}-\mathrm{ZrO}_{2}$ under hot compressed water (HCW) condition. Bioresour Technol 101(11): 4179-4186. 
Chatterjee C, Pong F, Sen A (2015) Chemical conversion pathways for carbohydrates. Green Chem 17(1): 40-71.

Chio C, Sain M, Qin W (2019) Lignin utilization: A review of lignin depolymerization from various aspects. Renew Sust Energ Rev 107: 232-249.

Chu D, Luo Z, Xin Y, Jiang C, Gao S, Wang Z et al (2021) One-pot hydrogenolysis of cellulose to bioethanol over Pd-Cu-WO $\mathrm{WO}_{\mathrm{x}} / \mathrm{SiO}_{2}$ catalysts. Fuel 292: 120311.

Delidovich I, Hausoul PJ, Deng L, Pfutzenreuter R, Rose M, Palkovits R (2016) Alternative monomers based on lignocellulose and their use for polymer production. Chem Rev 116(3): 1540-1599.

Deng T, Liu H (2013) Promoting effect of $\mathrm{SnO}_{x}$ on selective conversion of cellulose to polyols over bimetallic Pt-SnOx $/ \mathrm{Al}_{2} \mathrm{O}_{3}$ catalysts. Green Chem 15(1):116-124.

Deng W, Zhang Q, Wang Y (2014) Catalytic transformations of cellulose and cellulose-derived carbohydrates into organic acids. Catal Today 234: 31-41.

Foston M, Ragauskas AJ ( 2012) Biomass characterization: recent progress in understanding biomass recalcitrance. Ind Biotechnol 8(4):191-208.

Gallezot P (2008) Catalytic conversion of biomass: challenges and issues. ChemSusChem 1(8-9): 734-737.

Geboers J, Van de Vyver S, Carpentier K, Jacobs P, Sels B (2011a) Efficient hydrolytic hydrogenation of cellulose in the presence of Ru-loaded zeolites and trace amounts of mineral acid. Chem Commun 47(19): 5590-5592.

Geboers JA, Van de Vyver S, Ooms R, Op de Beeck B, Jacobs PA, Sels, BF (2011b) Chemocatalytic conversion of cellulose: opportunities, advances and pitfalls. Catal Sci Technol 1(5): 714-726.

Gérardy R, Debecker DP, Estager J, Luis P, Monbaliu JCM (2020) Continuous flow upgrading of selected C2-C6 platform chemicals derived from biomass. Chem Rev 120(15): 7219-7347.

Guha SK, Kobayashi H, Hara K, Kikuchi H, Aritsuka T, Fukuoka A (2011) Hydrogenolysis of sugar beet fiber by supported metal catalyst. Catal Commun 12(11): 980-983.

Guo S, Fang Q, Li Z, Zhang J, Zhang J, Li G (2019) Efficient base-free direct oxidation of glucose to gluconic acid over $\mathrm{TiO}_{2}$-supported gold clusters. Nanoscale 11(3): 1326-1334.

Gurbuz EI, Gallo JM, Alonso DM, Wettstein SG, Lim WY, Dumesic JA (2013) Conversion of hemicellulose into furfural using solid acid catalysts in gamma-valerolactone. Angew Chem Int Ed 52(4): 1270-1274. 
Han X, Guo Y, Liu X, Xia Q, Wang Y (2019) Catalytic conversion of lignocellulosic biomass into hydrocarbons: A mini review. Catal Today 319: 2-13.

Himmel ME, Ding SY, Johnson DK, Adney WS, Nimlos MR, Brady JW et al (2007) Biomass recalcitrance: engineering plants and enzymes for biofuels production. Science 315(5813): 804-807.

Hu L, Lin L, Wu Z, Zhou S, Liu S (2015) Chemocatalytic hydrolysis of cellulose into glucose over solid acid catalysts. Appl Catal B-Environ 174-175: 225-243.

Huang F, Li W, Zhang T, Li D, Liu Q, Zhu X et al (2018) Conversion of biomass-derived carbohydrates into 5-hydroxymethylfurfural catalyzed by sulfonic acid-functionalized carbon material with high strong-acid density in $\gamma$-valerolactone. Res Chem Intermediat 44(9): 5439-5453.

Huang Y, Fu Y (2013) Hydrolysis of cellulose to glucose by solid acid catalysts. Green Chem 15(5): 1095-1111.

Imman S, Khongchamnan P, Wanmolee W, Laosiripojana N, Kreetachat T, Sakulthaew C et al (2021) Fractionation and characterization of lignin from sugarcane bagasse using a sulfuric acid catalyzed solvothermal process. RSC Adv 11(43): 26773-26784.

Ji N, Zhang T, Zheng M, Wang A, Wang H, Wang X et al (2008) Direct catalytic conversion of cellulose into ethylene glycol using nickel-promoted tungsten carbide catalysts. Angew Chem Int Ed 47(44): 8510-8513.

Jing Y, Guo Y, Xia Q, Liu X, Wang Y (2019) Catalytic production of value-added chemicals and liquid fuels from lignocellulosic biomass. Chem 5(10): 2520-2546.

Jusner P, Bacher M, Hettegger H, Lê HQ, Potthast A, Sixta H et al (2021) On the chemical interactions of the biomass processing agents $\gamma$-valerolactone (GVL) and N-methylmorpholine-N-oxide (NMMO). Green Chem 23(16): 5832-5848.

Käldström M, Meine N, Farès C, Rinaldi R, Schüth F (2014a) Fractionation of 'water-soluble lignocellulose' into $\mathrm{C}_{5} / \mathrm{C}_{6}$ sugars and sulfur-free lignins. Green Chem 16(5): 2454-2462.

Käldström M, Meine N, Farès C, Schüth F, Rinaldi R (2014b) Deciphering 'water-soluble lignocellulose' obtained by mechanocatalysis: new insights into the chemical processes leading to deep depolymerization. Green Chem 16(7): 3528-3538.

Konwar LJ, Maki-Arvela P, Mikkola JP (2019) $\mathrm{SO}_{3} \mathrm{H}-$ Containing functional carbon materials: synthesis, Structure, and acid catalysis. Chem Rev 119(22): 11576-11630. 
Kumar S, Ali H, Kansal SK, Pandey A, Saravanamurugan S (2020) Sustainable production of sorbitol-a potential hexitol. In: Saravanamurugan S, Pandey A, Li H, Riisager A (ed) Biomass, Biofuels, Biochemicals, 9th edn. Elsevier, pp 259-281.

Shuai L, Amiri MT, Questell-Santiago YM, Florent Heroguel, Li Y, Kim H et al (2016) Formaldehyde stabilization facilitates lignin monomer production during biomass depolymerization. Science 354(6310): 329-333.

Lee, J (2015) Sorbitol, rubus fruit, and misconception. Food Chem 166: 616-622.

Li C, Xu G, Li K, Wang C, Zhang Y, Fu Y (2019a) A weakly basic $\mathrm{Co} / \mathrm{CeO}_{\mathrm{x}}$ catalytic system for one-pot conversion of cellulose to diols: Kungfu on eggs. Chem Commun 55(53): 7663-7666.

Li C, Xu G, Wang C, Ma L, Qiao Y, Zhang Y et al (2019b) One-pot chemocatalytic transformation of cellulose to ethanol over Ru-WO ${ }_{x} / H Z S M-5$. Green Chem 21(9): 2234-2239.

Li C, Zheng M, Wang A, Zhang T (2012) One-pot catalytic hydrocracking of raw woody biomass into chemicals over supported carbide catalysts: simultaneous conversion of cellulose, hemicellulose and lignin. Energ Environ Sci 5(4): 6383-6390.

Li H, Ren HF, Zhao BW, Liu CL, Yang RZ, Dong WS (2016) Production of lactic acid from cellulose catalyzed by alumina-supported $\mathrm{Er}_{2} \mathrm{O}_{3}$ catalysts. Res Chem Intermediat 42(9): 7199-7211.

Li Z, Su K, Ren J, Yang D, Cheng B, Kim CK et al (2018) Direct catalytic conversion of glucose and cellulose. Green Chem 20(4): 863-872.

Liao Y, Liu Q, Wang T, Long J, Ma L, Zhang Q (2014a) Zirconium phosphate combined with Ru/C as a highly efficient catalyst for the direct transformation of cellulose to C6 alditols. Green Chem 16(6): 3305-3312.

Liao Y, Liu Q, Wang T, Long J, Zhang Q, Ma L et al (2014b) Promoting hydrolytic hydrogenation of cellulose to sugar alcohols by mixed ball milling of cellulose and solid acid catalyst. Energ Fuel 28(9): 5778-5784.

Chen L, Dou J, Ma Q, Li N, Wu R, Bian H et al (2017) Rapid and near-complete dissolution of wood lignin at $\leq 80^{\circ} \mathrm{C}$ by a recyclable acid hydrotrope. Sci Adv, 3(9): e1701735.

Ling Z, Wang T, Makarem M, Santiago Cintrón M, Cheng HN, Kang X et al (2019) Effects of ball milling on the structure of cotton cellulose. Cellulose 26(1): 305-328.

Liu Q, Wang H, Xin H, Wang C, Yan L, Wang Y et al (2019) Selective cellulose hydrogenolysis to ethanol using Ni@C combined with phosphoric acid catalysts. ChemSusChem 12(17): 
Liu Y, Chen L, Wang T, Zhang Q, Wang C, Yan J et al (2015) One-pot catalytic conversion of raw lignocellulosic biomass into gasoline alkanes and chemicals over LiTaMoO6 and $\mathrm{Ru} / \mathrm{C}$ in aqueous phosphoric acid. ACS Sustain Chem Eng 3(8): 1745-1755.

Liu Y, Luo C, Liu H (2012) Tungsten trioxide promoted selective conversion of cellulose into propylene glycol and ethylene glycol on a ruthenium catalyst. Angew Chem Int Ed 51(13): 3249-3253.

Luo C, Wang S, Liu H (2007) Cellulose conversion into polyols catalyzed by reversibly formed acids and supported ruthenium clusters in hot water. Angew Chem Int Ed 119(40): 7780-7783.

Luo X, Li Y, Gupta NK, Sels B, Ralph J, Shuai L (2020) Protection strategies enable selective conversion of biomass. Angew Chem Int Ed 59(29): 11704-11716.

Lv M, Xin Q, Yin D, Jia Z, Yu C, Wang T et al (2020) Magnetically recoverable bifunctional catalysts for the conversion of cellulose to 1,2-Propylene Glycol. ACS Sustain Chem Eng 8(9): $3617-3625$.

Ma C, Cai B, Zhang L, Feng J, Pan H (2021) Acid-catalyzed conversion of cellulose into levulinic acid with biphasic solvent system. Front Plant Sci 12: 630807.

Ma L, Wang T, Liu Q, Zhang X, Ma W, Zhang Q (2012) A review of thermal-chemical conversion of lignocellulosic biomass in China. Biotechnol Adv 30(4): 859-873.

Mika LT, Csefalvay E, Nemeth A (2018) Catalytic conversion of carbohydrates to initial platform chemicals: chemistry and sustainability. Chem Rev 118(2): 505-613.

Onda A, Ochi T, Yanagisawa K (2009) Hydrolysis of cellulose selectively into glucose over sulfonated activated-carbon catalyst under hydrothermal conditions. Top Catal 52(6-7): 801-807.

Onda A, Ochi T, Yanagisawa K (2008) Selective hydrolysis of cellulose into glucose over solid acid catalysts. Green Chem 10(10): 1033-1037.

Questell-Santiago YM, Galkin MV, Barta K, Luterbacher JS (2020) Stabilization strategies in biomass depolymerization using chemical functionalization. Nat Rev Chem 4(6): 311-330.

Ragauskas AJ, Williams CK, Davison BH, Britovsek G, Cairney J, Eckert CA et al (2006) The path forward for biofuels and biomaterials. Science 311(5760): 484-489.

Rajak RC, Saha P, Singhvi M, Kwak D, Kim D, Lee H et al (2021) An eco-friendly biomass pretreatment strategy utilizing reusable enzyme mimicking nanoparticles for lignin 
Renders T, Cooreman E, Van den Bosch S, Schutyser W, Koelewijn SF, Vangeel T et al (2018) Catalytic lignocellulose biorefining in n-butanol/water: a one-pot approach toward phenolics, polyols, and cellulose. Green Chem 20(20): 4607-4619.

Rey-Raap N, Ribeiro LS, Órfão JJM, Figueiredo JL, Pereira MFR (2019) Catalytic conversion of cellulose to sorbitol over $\mathrm{Ru}$ supported on biomass-derived carbon-based materials. Appl Catal B-Environ 256: 117826.

Ribeiro LS, Orfao JJM, Pereira MFR (2017) Direct catalytic production of sorbitol from waste cellulosic materials. Bioresour Technol 232: 152-158.

Rinaldi R, Schuth F (2009) Acid hydrolysis of cellulose as the entry point into biorefinery schemes. ChemSusChem 2(12): 1096-1107.

Robertson GP, Hamilton SK, Barham BL, Dale BE, Izaurralde RC, Jackson RD et al (2017) Cellulosic biofuel contributions to a sustainable energy future: Choices and outcomes. Science 356(6345): eaal2324.

Ruppert AM, Weinberg K, Palkovits R (2012) Hydrogenolysis goes bio: from carbohydrates and sugar alcohols to platform chemicals. Angew Chem Int Ed 51(11): 2564-2601.

Suganuma S, Nakajima K, Kitano M, Yamaguchi D, Kato H, Hayashi S et al (2008) Hydrolysis of cellulose by amorphous carbon bearing $\mathrm{SO}_{3} \mathrm{H}, \mathrm{COOH}$, and $\mathrm{OH}$ Groups. J Am Chem Soc 130: $12787-12793$.

Scarsella M, de Caprariis B, Damizia M, De Filippis P (2020) Heterogeneous catalysts for hydrothermal liquefaction of lignocellulosic biomass: A review. Biomass Bioenerg 140: 105662.

Schutyser W, Renders T, Van den Bosch S, Koelewijn SF, Beckham GT, Sels BF (2018) Chemicals from lignin: an interplay of lignocellulose fractionation, depolymerisation, and upgrading. Chem Soc Rev 47(3): 852-908.

Serrano-Ruiz JC, Dumesic JA (2011) Catalytic routes for the conversion of biomass into liquid hydrocarbon transportation fuels. Energ Environ Sci 4(1): 83-99.

Shi N, Liu Q, He X, Cen H, Ju R, Zhang Y et al (2019) Production of lactic acid from cellulose catalyzed by easily prepared solid $\mathrm{Al}_{2}\left(\mathrm{WO}_{4}\right)_{3}$. Bioresource Technol Rep 5: 66-73.

Shimizu K, Furukawa H, Kobayashi N, Itaya Y, Satsuma A (2009) Effects of Brønsted and Lewis 
acidities on activity and selectivity of heteropolyacid-based catalysts for hydrolysis of cellobiose and cellulose. Green Chem 11(10): 1627-1632.

Shivhare A, Jampaiah D, Bhargava SK, Lee AF, Srivastava R, Wilson K (2021) Hydrogenolysis of lignin-derived aromatic ethers over heterogeneous catalysts. ACS Sustain Chem Eng 9(9): $3379-3407$.

Shuai L, Pan X (2012) Hydrolysis of cellulose by cellulase-mimetic solid catalyst. Energ Environ Sci 5(5): 6889-6894.

Song H, Wang P, Li S, Deng W, Li Y, Zhang Q et al (2019) Direct conversion of cellulose into ethanol catalysed by a combination of tungstic acid and zirconia-supported Pt nanoparticles. Chem Commun 55(30): 4303-4306.

Staples MD, Malina R, Barrett SRH (2017) The limits of bioenergy for mitigating global life-cycle greenhouse gas emissions from fossil fuels. Nat Energy 2(2): 16202.

Sudarsanam P, Peeters E, Makshina EV, Parvulescu VI, Sels BF (2019) Advances in porous and nanoscale catalysts for viable biomass conversion. Chem Soc Rev 48(8): 2366-2421.

Sudarsanam P, Zhong R, Van den Bosch S, Coman SM, Parvulescu VI, Sels BF (2018) Functionalised heterogeneous catalysts for sustainable biomass valorisation. Chem Soc Rev 47(22): 8349-8402.

Sun L, Lee JW, Yook S, Lane S, Sun Z, Kim SR et al (2021) Complete and efficient conversion of plant cell wall hemicellulose into high-value bioproducts by engineered yeast. Nat Commun 12(1): 4975.

Sun Q, Wang S, Aguila B, Meng X, Ma S, Xiao FS (2018a) Creating solvation environments in heterogeneous catalysts for efficient biomass conversion. Nat Commun 9(1): 3236.

Sun Z, Bottari G, Afanasenko A, Stuart MCA, Deuss PJ, Fridrich B (2018b) Complete lignocellulose conversion with integrated catalyst recycling yielding valuable aromatics and fuels. Nat Catal 1(1): 82-92.

Sun Z, Fridrich B, de Santi A, Elangovan S, Barta K (2018c) Bright side of lignin depolymerization: toward new platform chemicals. Chem Rev 118(2): 614-678.

Tian D, Shen F, Hu J, Huang M, Zhao L, He J (2022) Complete conversion of lignocellulosic biomass into three high-value nanomaterials through a versatile integrated technical platform. Chem Eng J 428: 131373. 
Tindall DJ, Mader S, Kindler A, Rominger F, Hashmi ASK, Schaub T (2021) Selective and scalable synthesis of sugar alcohols by homogeneous asymmetric hydrogenation of unprotected ketoses. Angew Chem Int Ed 60(2): 721-725.

Tyufekchiev M, Duan P, Schmidt-Rohr K, Granados Focil S, Timko MT, Emmert MH (2018) Cellulase-inspired solid acids for cellulose hydrolysis: structural explanations for high catalytic activity. ACS Catal 8(2): 1464-1468.

Van de Vyver S, Geboers J, Dusselier M, Schepers H, Vosch T, Zhang L et al (2010) Selective bifunctional catalytic conversion of cellulose over reshaped $\mathrm{Ni}$ particles at the tip of carbon nanofibers. ChemSusChem 3(6): 698-701.

Van de Vyver S, Geboers J, Schutyser W, Dusselier M, Eloy P, Dornez E et al (2012) Tuning the acid/metal balance of carbon nanofiber-supported nickel catalysts for hydrolytic hydrogenation of cellulose. ChemSusChem 5(8): 1549-1558.

van Putten RJ, van der Waal JC, de Jong E, Rasrendra CB, Heeres HJ, de Vries JG (2013) Hydroxymethylfurfural, a versatile platform chemical made from renewable resources. Chem Rev 113(3): 1499-1597.

Vanneste J, Ennaert T, Vanhulsel A, Sels B (2017) Unconventional pretreatment of lignocellulose with low temperature plasma. ChemSusChem 10(1): 14-31.

Verdía P, Brandt A, Hallett JP, Ray MJ, Welton T (2014) Fractionation of lignocellulosic biomass with the ionic liquid 1-butylimidazolium hydrogen sulfate. Green Chem 16(3): 1617-1627.

vom Stein T, Grande PM, Kayser H, Sibill F, Leitner W, Domínguez de María P (2011) From biomass to feedstock: one-step fractionation of lignocellulose components by the selective organic acid-catalyzed depolymerization of hemicellulose in a biphasic system. Green Chem 13(7): $1772-1777$.

Wang C, Zhang X, Liu Q, Zhang Q, Chen L, Ma L (2020a) A review of conversion of lignocellulose biomass to liquid transport fuels by integrated refining strategies. Fuel Process Technol 208: 106485.

Wang H, Yang B, Zhang Q, Zhu W (2020b) Catalytic routes for the conversion of lignocellulosic biomass to aviation fuel range hydrocarbons. Renew Sust Energ Rev 120: 109612.

Wang S, Chen K, Wang Q (2018) Ytterbium triflate immobilized on sulfo-functionalized SBA-15 catalyzed conversion of cellulose to lactic acid. J Porous Mat 25(5): 1531-1539. 
Wang W, Wu H, Shakeel U, Wang C, Yan T, Xu X et al (2021) Synergistic effect of acidity balance and hydrothermal pretreatment severity on alkali extraction of hemicelluloses from corn stalk. Biomass Convers Bioref. https://doi.org/10.1007/s13399-020-01196-w

Wang Y, Zhang Y, Li C, Wang M, Cu H, Yi W et al (2020c) Temperature-responsive solid acid catalyst for cellulose hydrolysis to HMF. ChemistrySelect 5(14): 4136-4142.

Wang Y, Zhang Y, Wang J, Wang M, Cui H, Yi W et al (2020d) Temperature-responsive HCl-releasing catalysts for cellulose hydrolysis into glucose. Catal Lett 150(11): 3184-3195.

Weingarten R, Conner WC, Huber GW (2012) Production of levulinic acid from cellulose by hydrothermal decomposition combined with aqueous phase dehydration with a solid acid catalyst. Energ Environ Sci 5(6): 7559-7574.

Wen Z, Yu L, Mai F, Ma Z, Chen H, Li Y (2019) Catalytic conversion of microcrystalline cellulose to glucose and 5-Hydroxymethylfurfural over a niobic acid catalyst. Ind Eng Chem Res 58(38): $17675-17681$.

Wittwer RA, Franz Bender S, Hartman K, Hydbom S, Lima RAA, Loaiza V et al (2021) Organic and conservation agriculture promote ecosystem multifunctionality. Sci Adv 7(34): eabg6995.

Wong SS, Shu R, Zhang J, Liu H, Yan N (2020) Downstream processing of lignin derived feedstock into end products. Chem Soc Rev 49(15): 5510-5560.

Woolf D, Lehmann J, Lee DR (2016) Optimal bioenergy power generation for climate change mitigation with or without carbon sequestration. Nat Commun 7: 13160 .

Xia Q, Chen Z, Shao Y, Gong X, Wang H, Liu X et al (2016) Direct hydrodeoxygenation of raw woody biomass into liquid alkanes. Nat Commun 7: 11162.

Xiang M, Liu J, Fu W, Tang T, Wu D (2017) Improved activity for cellulose conversion to levulinic acid through hierarchization of ETS-10 zeolite. ACS Sustain Chem Eng 5(7): 5800-5809.

Xu G, Wang A, Pang J, Zhao X, Xu J, Lei N et al (2017) Chemocatalytic conversion of cellulosic biomass to methyl glycolate, ethylene glycol, and ethanol. ChemSusChem 10(7): 1390-1394.

Yabushita M, Kobayashi H, Fukuoka A (2014) Catalytic transformation of cellulose into platform chemicals. Appl Catal B-Environ 145: 1-9.

Yang J, Lu X, Liu X, Xu J, Zhou Q, Zhang S (2017) Rapid and productive extraction of high purity cellulose material via selective depolymerization of the lignin-carbohydrate complex at mild conditions. Green Chem 19(9): 2234-2243. 
Yang L, Su J, Carl S, Lynam JG, Yang X, Lin H (2015) Catalytic conversion of hemicellulosic biomass to lactic acid in $\mathrm{pH}$ neutral aqueous phase media. Appl Catal B-Environ 162: 149-157.

Yang M, Qi H, Liu F, Ren Y, Pan X, Zhang L et al (2019) One-pot production of cellulosic ethanol via tandem catalysis over a multifunctional Mo/Pt/WOx catalyst. Joule 3(8): 1937-1948.

Ye J, Chen C, Zheng Y, Zhou D, Liu Y, Chen D et al (2021) Efficient conversion of cellulose to lactic acid over yttrium modified siliceous Beta zeolites. Appl Catal A-Gen 619: 118133.

Lin YC, Huber GW (2009) The critical role of heterogeneous catalysis in lignocellulosic biomass conversion. Energ Environ Sci 2: 68-80.

Yu Z, Zhang L, Han Y, Li S, Hu J, Shi F (2021) Thick pore wall and strong stability of mesoporous silica supported HPW materials: Highly efficient catalysts for cellulose hydrolysis reaction. Mater Lett 282: 128841.

Liao Y, Koelewijn SF, Van den Bossche G, Van Aelst J, Van den Bosch S, Renders T et al (2020) A sustainable wood biorefinery for low-carbon footprint chemicals production. Science 367(6484): 1385-1390.

Zeng M, Pan X (2020) Insights into solid acid catalysts for efficient cellulose hydrolysis to glucose: progress, challenges, and future opportunities. Catal Rev. DOI: $10.1080 / 01614940.2020 .1819936$

Zhang Q, Guo Z, Zeng X, Ramarao B, Xu F (2021a) A sustainable biorefinery strategy: Conversion and fractionation in a facile biphasic system towards integrated lignocellulose valorizations. Renew Energ 179: 351-358.

Zhang Q, Wan Z, Yu IKM, Tsang DCW (2021b) Sustainable production of high-value gluconic acid and glucaric acid through oxidation of biomass-derived glucose: A critical review. J Clean Prod 312:127745.

Zhang Q, Xiang X, Ge Y, Yang C, Zhang B, Deng K (2020) Selectivity enhancement in the g-C3N4-catalyzed conversion of glucose to gluconic acid and glucaric acid by modification of cobalt thioporphyrazine. J Catal 388: 11-19.

Zhang X, Wilson K, Lee AF (2016) Heterogeneously catalyzed hydrothermal processing of C5-C6 sugars. Chem Rev 116(19): 12328-12368.

Zhang Y, He H, Liu Y, Wang Y, Huo F, Fan M et al 2019. Recent progress in theoretical and computational studies on the utilization of lignocellulosic materials. Green Chem 21(1): 9-35. 
Zhang Y, Wang J, Li X, Liu X, Xia Y, Hu B et al (2015) Direct conversion of biomass-derived carbohydrates to 5-hydroxymethylfurural over water-tolerant niobium-based catalysts. Fuel 139: 301-307.

Zhang Z, Huber GW (2018) Catalytic oxidation of carbohydrates into organic acids and furan chemicals. Chem Soc Rev 47(4): 1351-1390.

Zhang Z, Song J, Han B (2017) Catalytic transformation of lignocellulose into chemicals and fuel products in ionic liquids. Chem Rev 117(10): 6834-6880.

Zhao S, Cheng M, Li J, Tian J, Wang X (2011) One pot production of 5-hydroxymethylfurfural with high yield from cellulose by a Bronsted-Lewis-surfactant-combined heteropolyacid catalyst. Chem Commun 47(7): 2176-2178.

Zheng M, Pang J, Sun R, Wang A, Zhang T (2017) Selectivity control for cellulose to diols: dancing on eggs. ACS Catal 7(3): 1939-1954.

Zhu S, Xue Y, Guo J, Cen Y, Wang J, Fan W (2016) Integrated conversion of hemicellulose and furfural into $\gamma$-valerolactone over $\mathrm{Au} / \mathrm{ZrO}_{2}$ catalyst combined with ZSM-5. ACS Catal 6(3): 2035-2042.

Zunita M, Wahyuningrum D, Buchari, Bundjali B, Gede Wenten I, Boopathy R (2020) The performance of 1,3-dipropyl-2-(2-propoxyphenyl)-4,5-diphenylimidazolium iodide based ionic liquid for biomass conversion into levulinic acid and formic acid. Bioresour Technol 315: 123864.

Zuo Y, Zhang Y, Fu Y (2014) Catalytic conversion of cellulose into levulinic acid by a sulfonated chloromethyl polystyrene solid acid catalyst. ChemCatChem 6(3): 753-757. 